\title{
Young managers in Eastern Europe
}

Transformation processes use to be much more than a large area of problems and difficulties. They always form arenas for young people appearing and searching for their chances in a highly dynamic environment. In Eastern Europe too, we are currently confronted with a large number of new businessmen (and women), with new power groups dominating the situation.

Maybe it is still too early to conduct an overall analysis or even to theoretize these phenomena. (In this respect perhaps III Chemnitz East Forum on Managers in the Transformation Process next year could be an interesting date ... - see p. 59). Nevertheless we should have a look at it, and perhaps the best way to do it is by listening to a few of these young managers, to their reflections, opinions and experiences, sometimes, maybe, a bit puzzling, often quite exciting, always standing for a newly developing heterogeneous generation of managers in the East European Transformation Process.

Thomas Steger

\section{Questions put to the managers}

1. What does your personal career look like? (origin, education/formation, job career)

2. What reasons did you prompt to take on the job you do today?

3. Please give a short portrait of your company and your occupation (branch, volume, property relations, legal form etc.)

4. What are the most difficult problems you are struggling with at the moment?

5. Assuming a young person intends to start any business activities in your country, what would you recommend him or her to do (or not to do)?

6. What do you think about future developments and perspectives for you, your company and your region/country?

\section{Fragen an die Manager}

1. Was ist Ihr persönlicher Werdegang? (Herkunft, Bildungsweg, berufliche Laufbahn)

2. Welche Überlegungen spielten bei der Übernahme Ihrer heutigen Tätigkeit eine Rolle?

3. Stellen Sie bitte kurz Ihre Firma und Ihre Tätigkeit vor! (Branche, Größe, Eigentumsverhältnisse, Rechtsform usw.) 
4. Welches sind die gravierendsten Probleme, mit denen Sie sich momentan auseinandersetzen müssen?

5. Was würden Sie anderen Personen, die in Ihrem Land unternehmerisch tätig werden wollen, besonders empfehlen?

6. Wie schätzen Sie die zukünftige Entwicklung für sich, Ihre Firma und Ihre Region/Land ein?

\section{CALL FOR PAPERS III CHEMNITZ EAST FORUM}

We are pleased to announce a call for papers for the III Chemnitz East Forum taking place at Technical University Chemnitz-Zwickau from March 5-7, 1997 dealing with

\section{Managers in the Transformation Process of Eastern Europe}

Chairman: $\quad$ Prof Rainhart Lang, TU Chemnitz-Zwickau

Key note speaker: Prof Fred Luthans, University of Nebraska Lincoln

Special topics treated in workshops and jointly chaired by a German and an East European specialist are:

I Manager careers, old elites/new elites

II Values and management attitudes

III Leadership styles and work relations

IV Management development

$\mathrm{V}$ Management problems in the practice of Eastern Europe

Applications and papers (max 2 pages) are welcome and should be received not later than October 31, 1996. As far as possible participants from Eastern European countries are will have their costs for transport and accommodation refunded.

For further information please contact:

Mr Thomas Steger

Technical University Chemnitz-Zwickau

phone +49-371-5314159

fax +49-371-5313987

e-mail t.steger@wirtschaft.tu-chemnitz.de 